\title{
T-screen and yeast assay for the detection of the thyroid-disrupting activities of cadmium, mercury, and zinc
}

\author{
Jian $\mathrm{Li}^{1} \cdot$ Yun $\mathrm{Liu}^{2} \cdot$ Dongdong Kong ${ }^{1} \cdot$ Shujuan $\operatorname{Ren}^{1} \cdot \mathrm{Na} \mathrm{Li}^{3}$
}

Received: 11 November 2015 / Accepted: 11 January 2016 / Published online: 9 February 2016

(C) Springer-Verlag Berlin Heidelberg 2016

\begin{abstract}
In the present study, a two-hybrid yeast bioassay and a T-screen were used to screen for the thyroid receptor (TR)-disrupting activity of select metallic compounds $\left(\mathrm{CdCl}_{2}\right.$, $\mathrm{ZnCl}_{2}, \mathrm{HgCl}_{2}, \mathrm{CuSO}_{4}, \mathrm{MnSO}_{4}$, and $\mathrm{MgSO}_{4}$ ). The results reveal that none of the tested metallic compounds showed TRagonistic activity, whereas $\mathrm{ZnCl}_{2}, \mathrm{HgCl}_{2}$, and $\mathrm{CdCl}_{2}$ demonstrated TR antagonism. For the yeast assay, the dose-response relationship of these metallic compounds was established, and the concentrations producing $20 \%$ of the maximum effect of $\mathrm{ZnCl}_{2}, \mathrm{HgCl}_{2}$, and $\mathrm{CdCl}_{2}$ were $9.1 \times 10^{-5}, 3.2 \times 10^{-6}$, and $1.2 \times 10^{-6} \mathrm{~mol} / \mathrm{L}$, respectively. The T-screen also supported the finding that $\mathrm{ZnCl}_{2}, \mathrm{HgCl}_{2}$, and $\mathrm{CdCl}_{2}$ decreased the cell proliferation at concentrations ranging from $10^{-6}$ to $10^{-4} \mathrm{~mol} /$ L. Furthermore, the thyroid-disrupting activity of metallic compounds in environmental water samples collected from the Guanting Reservoir, Beijing, China was evaluated. Solid-phase extraction was used to separate the organic
\end{abstract}

Responsible editor: Philippe Garrigues

Electronic supplementary material The online version of this article (doi:10.1007/s11356-016-6095-5) contains supplementary material, which is available to authorized users.

Jian Li

lijian@bnu.edu.cn

1 Engineering Research Center of Groundwater Pollution Control and Remediation, Ministry of Education, College of Water Sciences, Beijing Normal University, Beijing 100875, China

2 South China Institute of Environmental Science, Ministry of Environmental Protection, No. 7 West Street, Yuancun, Guangzhou 510655, China

3 State Key Laboratory of Environmental Aquatic Chemistry, Research Center for Eco-Environmental Sciences, Chinese Academy of Sciences, P. O. Box 2871, Beijing 100085, China extracts, and a modified two-hybrid yeast bioassay revealed that the metallic compounds in the water samples could affect thyroid hormone-induced signaling by decreasing the binding of the thyroid hormone. The addition of ethylenediaminetetraacetic acid $(30 \mathrm{mg} / \mathrm{L})$ could eliminate the effects. Thus, the cause(s) of the thyroid toxicity in the water samples appeared to be partly related to the metallic compounds.

Keywords In vitro bioassay · Toxic metals · Thyroid receptor $\cdot$ Thyroid-disrupting activity

\section{Introduction}

Heavy metals are widely dispersed in the environment and are a major concern in the modern industrial context of pollution because they tend to bioaccumulate (Denier et al. 2009). Heavy metals have the ability to cause detrimental health effects by affecting reproduction, fertility, as well as the immune and neuronal systems, and by leading to carcinogenesis (Shiue 2015; Martins et al. 2014). In the last 15 years, the potential health threat posed by endocrine-disrupting chemicals (EDCs) has come to the forefront of toxicology and represents a major concern among the public community (Buha et al. 2013). Several studies based on in vitro and in vivo assays have revealed that heavy metals, such as cadmium $(\mathrm{Cd})$, mercury $(\mathrm{Hg})$, and zinc $(\mathrm{Zn})$, act as potential EDCs by activating estrogen receptor (ER) and modulating the estrogenic activity of endogenous hormones (Denier et al. 2009; Isidori et al. 2010; Ali et al. 2010). However, the endocrine disruption induced by chemicals is not restricted to the sex hormone system but also includes thyroid hormone (TH) disruption (Murk et al. 2013).

Thyroid hormones participate in several important physiological processes, including the regulation of energy metabolism, growth and differentiation, and the development and 
maintenance of brain function (Murk et al. 2013). However, increasing evidence from animal and in vitro studies indicates that the thyroid is vulnerable to endocrine-disrupting effects (Boas et al. 2012). Industrial chemicals characterized as thyroid-disrupting chemicals (TDCs) include polychlorinated biphenyls (PCBs), dioxins, brominated flame retardants (BFRs), pesticides, perfluorinated chemicals (PFCs), phenols, phthalate esters (PAEs), and perchlorate (Boas et al. 2012; Shi et al. 2009).

Although the research focus has mainly been placed on organic compounds, metallic compounds, particularly heavy metal compounds, are starting to be studied for their ability to disrupt the TH signaling pathways of various living organisms (Curčić et al. 2012; Hammouda et al. 2008). For example, Zn is required for the proper function of 1,5'-deiodinase, which is the enzyme required for the conversion of thyroxine $\left(\mathrm{T}_{4}\right)$ into triiodothyronine $\left(\mathrm{T}_{3}\right)$. Another metal, $\mathrm{Cd}$, has been reported to inhibit thyroid function and induce thyroid dysfunction (Buha et al. 2013; Gupta et al. 1997; Gupta and Kar 1999). Furthermore, there is literature data supporting the hypothesis that the direct influence of toxic heavy metals, for example manganese $(\mathrm{Mn})$, copper $(\mathrm{Cu})$, and $\mathrm{Zn}$, on thyrocytes plays a role in thyroid cancer etiology (Yaman et al. 2007).

The effects of THs depend on signal transduction via the binding of nuclear thyroid receptors (TRs), which subsequently interact with thyroid-response elements (TREs) in the promoter regions of genes to either enhance or inhibit gene transcription (Yen et al. 2006). However, the available data on the thyroid-disrupting effects of heavy metals mediated by the interaction with the TR are limited. A previous study reported that $\mathrm{Zn}$ plays a role in $\mathrm{T}_{3}$ binding to TR and is crucial for the binding of TR to its target genes (Wada and King 1986; Surks et al. 1989). Zn-chelation enhances the ability of $\mathrm{T}_{3}$ to induce target gene expression in rat pituitary tumor cells $\left(\mathrm{GH}_{3}\right)$ (Sciaudone et al. 2000). Moreover, Lukaski et al. (1995) found an inverse relationship between the TR binding of $\mathrm{T}_{3}$ and the $\mathrm{Cu}$. Taken together, all of these findings suggest that heavy metals may disrupt TR-mediated transcription and affect the thyroid system.

Thus, investigations of the heavy metals that may disrupt TR-mediated transcription should be promoted in order to resolve some of the environmental threats to human health. The objective of the present study was to employ a T-screen and a two-hybrid TR yeast assay to evaluate the thyroid disruption caused by selected heavy metals. The selected metals, namely $\mathrm{Cd}, \mathrm{Zn}, \mathrm{Hg}, \mathrm{Cu}, \mathrm{Mn}$, and magnesium $(\mathrm{Mg})$, are common pollutants in the environment and major sources of concern for both human and wildlife health (Fu et al. 2014). Environmental water samples were incorporated in this study because heavy metals are widely dispersed into the aquatic environment and thereby form a source of exposure for organisms in aquatic food chains.

\section{Materials and methods}

\section{Chemicals}

3,3',5-Triiodo-L-thyronine $\left(\mathrm{T}_{3}, 95 \%\right)$ and dimethylsulfoxide (DMSO, $99.5 \%$ ) were purchased from Sigma Chemical (St. Louis, MO, USA). Amiodarone hydrochloride (AH) was purchased from Shanghai Pharmaceutical (Shanghai, China). HPLC-grade dichloromethane, hexane, and methanol were purchased from Fisher Scientific (Fair Lawn, NJ, USA).

Cadmium chloride $\left(\mathrm{CdCl}_{2}\right)$, zinc chloride $\left(\mathrm{ZnCl}_{2}\right)$, mercury chloride $\left(\mathrm{HgCl}_{2}\right)$, cupric sulfate $\left(\mathrm{CuSO}_{4}\right)$, manganese sulfate $\left(\mathrm{MnSO}_{4}\right)$, and magnesium sulfate $\left(\mathrm{MgSO}_{4}\right)$ were obtained from Sigma-Aldrich. Stock solutions for all of the compounds were prepared at final chemical concentrations of $0.02 \mathrm{~mol} / \mathrm{L}$ as reported by Denier et al. (2009). Seven concentrations of chemical, ranging from $2 \times 10^{-9} \mathrm{~mol} / \mathrm{L}$ to $2 \times 10^{-3} \mathrm{~mol} / \mathrm{L}$, were obtained by serial dilutions.

\section{Sample collection and processing}

Environmental water samples were collected in September 2012 from the Guanting Reservoir in China. The locations of the eight sampling sites are shown in Fig. 1. Each of the water samples $(4 \mathrm{~L})$ was collected in seperate amber glass bottle. The samples were stored at $4{ }^{\circ} \mathrm{C}$ prior to treatment. All of the samples were treated within $24 \mathrm{~h}$.

The environmental water samples, procedure blanks (MilliQ water, conductivity of $18.2 \Omega$ ), and control samples ( $\mathrm{a} \mathrm{T}_{3}$ or $\mathrm{T}_{3}+\mathrm{AH}$ solution in Milli-Q water) were filtered through glass fiber filters $(0.7 \mu \mathrm{m}$, Waterman, England) to remove insoluble materials. After filtration, volumes of $500 \mathrm{~mL}$ of the water samples were collected and stored at $4{ }^{\circ} \mathrm{C}$ in glass containers until used for the modified two-hybrid TR yeast assay. The other water samples, including the procedure blanks, were treated according to procedures described ( $\mathrm{Li}$ et al. 2010). Solid-phase extraction was performed using a C18 cartridge (500 mg, Waters, USA) conditioned according to the manufacturer's directions. The cartridges were forced under vacuum at a flow rate of approximately $6 \mathrm{~mL} / \mathrm{min}$. After extraction, $500 \mathrm{~mL}$ of residual water and $500 \mathrm{~mL}$ of residual water added with ethylenediaminetetraacetic acid (EDTA, $30 \mathrm{mg} / \mathrm{L}$ ) were also collected for bioassay using the modified two-hybrid TR yeast assay.

\section{The conventional two-hybrid TR yeast assay}

The bioassays, including the agonistic and the antagonistic activity tests, were used to evaluate the thyroid-disrupting activity of the selected heavy metal compounds, as described by $\mathrm{Li}$ et al. (2008). All of the experiments were performed in triplicate. Each assay group comprised the chemicals, the 
Fig. 1 Sampling sites in the Guanting Reservoir

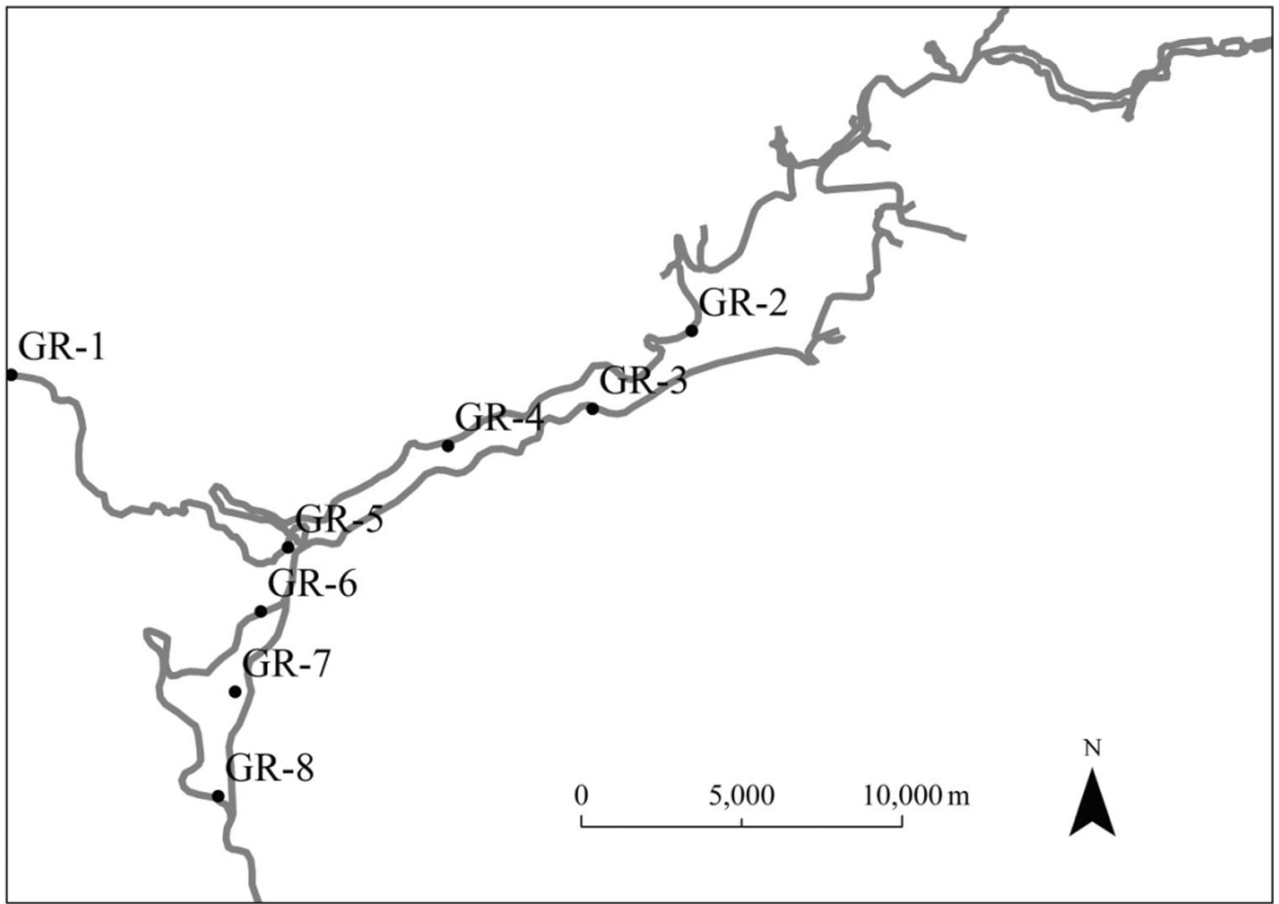

positive control $\left(\mathrm{T}_{3}\right.$ for agonistic activity or $\mathrm{T}_{3}+\mathrm{AH}$ for antagonistic activity), and the negative control (DMSO).

The yeast strain hTR-GRIP1 was grown overnight at $30{ }^{\circ} \mathrm{C}$ and $130 \mathrm{rpm}$ with vigorous shaking. During the assay, exponentially growing overnight cultures were diluted with a synthetic dextrose/-Leu/-Trp (SD/-Leu/-Trp) medium to an $\mathrm{OD}_{600 \mathrm{~nm}}$ of 0.75 . The serial dilutions $(5 \mu \mathrm{L})$ of the chemicals were combined with $995 \mu \mathrm{L}$ of medium containing $5 \times 10^{3}$ yeast cells $/ \mathrm{mL}$, resulting in a test culture. To assess the antagonistic activities, the chemicals were tested in the presence of $2.5 \times 10^{-7} \mathrm{~mol} /$ $\mathrm{L} \mathrm{T}_{3}$, which produced a submaximal stimulatory response. The DMSO volume did not exceed $1.0 \%$ of the total volume. Two hundred microliters of the test cultures were transferred into each well of a 96-well plate, and the plate was incubated at $30{ }^{\circ} \mathrm{C}$ with vigorous orbital shaking $(800 \mathrm{rpm})$ on a titer plate shaker (Heidolph TITRAMAX 1000 , Germany) for $2 \mathrm{~h}$. The cell density of the culture was then measured using 600-nm irradiation (TECAN GENios A-5002, Austria). Fifty microliters of the test culture was transferred onto a new 96-well plate, and after the addition of $120 \mu \mathrm{L}$ of Z-buffer (disodium hydrogen phosphate dodecahydrate $21.51 \mathrm{~g} / \mathrm{L}$, sodium dihydrogen phosphate dehydrate $6.22 \mathrm{~g} / \mathrm{L}$, potassium chloride $0.75 \mathrm{~g} / \mathrm{L}$, and magnesium chloride heptahydrate $0.25 \mathrm{~g} /$ L) and $20 \mu \mathrm{L}$ of chloroform, the assays were carefully mixed (vortexed for $25 \mathrm{~s}$ ) and pre-incubated for $5 \mathrm{~min}$ at $30{ }^{\circ} \mathrm{C}$. The enzyme reaction was initiated by the addition of $40 \mu \mathrm{L}$ of $o$-nitrophenyl- $\beta$-D-galactopyranoside (13.3 $\mathrm{mmol} / \mathrm{L}$, dissolved in Z-buffer). The assays were incubated at $30{ }^{\circ} \mathrm{C}$ for $60 \mathrm{~min}$ on a titer plate shaker. The reactions were terminated by the addition of $100 \mu \mathrm{L}$ of $1 \mathrm{~mol} / \mathrm{L} \mathrm{Na}_{2} \mathrm{CO}_{3}$. Two microliters of the supernatant were transferred to a new 96-well plate, and the $\mathrm{OD}_{420 \mathrm{~nm}}$ was determined. The $\beta$-galactosidase activity was calculated according to equations described by Li et al. (2008).

\section{The modified two-hybrid TR yeast assay}

A rapid and easy bioassay without water sample extraction, concentration, or sterilization was developed by Li et al. (2014). Exponentially growing overnight cultures were diluted with $\mathrm{SD} /-\mathrm{Leu} /$-Trp medium to an $\mathrm{OD}_{600 \mathrm{~nm}}$ of 0.75 . Five-milliliter samples of the cultures were centrifuged at $1000 \mathrm{~g}$ for $5 \mathrm{~min}$ (Sigma Laborzentrifugen 2K15, Germany), and the supernatant was discarded. The yeast cells and $0.5 \mathrm{~mL}$ of $10 \times \mathrm{SD} /-\mathrm{Leu} /$-Trp medium were added to $4.5 \mathrm{~mL}$ of the water samples to yield the test culture. For the antagonistic test, $12.5 \mu \mathrm{L}$ of $10^{-4} \mathrm{~mol} / \mathrm{L} \mathrm{T}_{3}$ (dissolved in DMSO) was added to the test culture, and the volume of DMSO did not exceed $0.25 \%$ of the total volume. The test cultures were incubated at $30{ }^{\circ} \mathrm{C}$ with vigorous orbital shaking (130 rpm) on a shaking incubator (HZQ-Q, China) for $2 \mathrm{~h}$. Two hundred microliters of the test cultures were transferred into each well of a 96-well plate, and the cell density of the culture was measured under 600-nm irradiation (TECAN GENios A-5002, Austria). The $\beta$-galactosidase activity was tested as described in "The conventional twohybrid TR yeast assay" section. 


\section{T-screen procedure}

Rat pituitary tumor cells $\left(\mathrm{GH}_{3}\right.$, purchased from the Cell Center of Basic Medicine, Beijing, China) were cultured at $37{ }^{\circ} \mathrm{C}$ and $5 \%(v / v) \mathrm{CO}_{2}$ in a humid atmosphere in Ham's F10 medium with HEPES (GibcoBRL, New York, USA) supplemented with $2.5 \%$ fetal calf serum (Gibco, Australian) and $15 \%$ horse serum (Gibco, New Zealand). Prior to the T-screen procedure, the cells were incubated for $48 \mathrm{~h}$ in serum-free DMEM/F12 medium (PCM medium) to deplete the cells of the thyroid hormones, as described by Sirbasku et al. (1991). The T-screen was performed as described previously (Gutleb et al. 2005) with minor modifications. The old serum-free PCM medium was removed, and the cells were collected from the culture flask. The cell density was counted, and the cells were diluted with PCM to a density of approximately 2500 cells/well. Two hundred microliters of the cultures were transferred into each well of a 96-well plate, and the plate was incubated for $24 \mathrm{~h}$. The serial dilutions $(5 \mu \mathrm{L})$ of the chemicals were combined with $995 \mu \mathrm{L}$ of the PCM medium to yield the test medium. To assess the antagonistic activities, the chemicals were tested in the presence of $2.5 \times 10^{-10} \mathrm{~mol} / \mathrm{L}$ $\mathrm{T}_{3}$, which produced a submaximal stimulatory response. After discarding the old medium, $200 \mu \mathrm{L}$ of the test medium was transferred onto a 96-well plate. The plate was incubated for $96 \mathrm{~h}$, and the test medium was replaced every $48 \mathrm{~h}$. After exposure, the cell proliferation was determined by the $3-(4$, 5-dimethylthiazol-2-yl)-2,5-diphenyltetrazolium bromide (MTT) assay. The medium was removed and replaced with $50 \mu \mathrm{L}$ of PBS (potassium dihydrogen phosphate $0.27 \mathrm{~g} / \mathrm{L}$, disodium hydrogen phosphate $1.42 \mathrm{~g} / \mathrm{L}$, potassium chloride $0.2 \mathrm{~g} / \mathrm{L}$, and sodium chloride $8.0 \mathrm{~g} / \mathrm{L}$ ) containing $0.5 \mathrm{mg} / \mathrm{mL}$ MTT, which had been pre-incubated for $4 \mathrm{~h}$ at $37^{\circ} \mathrm{C}$. The medium was then removed, and $150 \mu \mathrm{L}$ of DMSO was quickly added to each well to extract the dye. After an additional $10 \mathrm{~min}$ at room temperature and rapid agitation on a microtiter plate shaker, the plate was transferred to a microplate reader (TECAN GENios A-5002, Austria) equipped with a 490-nm filter to measure the absorbance of the extracted dye.

\section{Cytotoxicity}

To ensure that the increased/reduced activities observed by the bioassay were caused by true agonistic/antagonistic responses and not by cytotoxicity, the viability of the cells exposed to chemicals at the maximum assay concentration was measured.

The yeast cells were placed as in the original assay and then exposed for $2 \mathrm{~h}$ to medium containing chemicals. The cell viability was then determined spectrophotometrically as the change in the cell density $\left(\mathrm{OD}_{600 \mathrm{~nm}}\right)$ in the assay medium. The results were rejected when the ratio $\left(\mathrm{OD}_{600} \mathrm{~nm}\right.$-exposure medium $/ \mathrm{OD}_{600}$ nm-blank medium $)$ exceeded $110 \%$ or was less than $90 \%$.
$\mathrm{GH}_{3}$ cells are not able to divide in PCM without $\mathrm{T}_{3}$ but retain their basal activity. To determine the cytotoxicity, $\mathrm{GH}_{3}$ cells were plated and cultured with the PCM-containing test chemicals for $96 \mathrm{~h}$. The cell viability was then tested by the MTT assay as described previously. The concentrations of the test compounds that inhibited the basal viability of $\mathrm{GH}_{3}$ cells cultured in PCM without $\mathrm{T}_{3}$ were considered to be cytotoxic (Gutleb et al. 2005).

\section{Data analysis}

The median-effect concentration $\left(\mathrm{EC}_{50}\right)$ and the concentration reducing $20 \%$ of the maximum effect $\left(\mathrm{RIC}_{20}\right)$ for the compounds for which a dose-response curve could be constructed were calculated. The dose-response curve was generated using a four-parameter logistic model based on the Marquardt-Levenberg algorithm (Sigmaplot $4.0^{\circledR}$, SPSS, Chicago, IL, USA) (Rehmann et al. 1999).

\section{Results}

\section{Cytotoxic effects of metallic compounds}

To quantify the cytotoxic effects, we measured the survival of yeast cells after treatment with the six metallic compounds at the maximum assay concentration $\left(10^{-4} \mathrm{~mol} / \mathrm{L}\right)$. The results suggested that the yeast cell viability of the $\mathrm{CdCl}_{2}$ and $\mathrm{HgCl}_{2}$ samples was significantly different from that of the reference culture $(p<0.05)$. The percent growth inhibitions were calculated to be 11.8 and $15.8 \%$ for $\mathrm{CdCl}_{2}$ and $\mathrm{HgCl}_{2}$, respectively, showing that these chemicals exerted cytotoxic effects on yeast cells (Fig. 2a). The other chemicals did not exhibit any cytotoxic effects, even at the maximum assay concentration.

After treatment of $\mathrm{GH}_{3}$ cells with $\mathrm{CdCl}_{2}, \mathrm{ZnCl}_{2}$, and $\mathrm{HgCl}_{2}$, we also observed an inhibition of cellular growth with $\mathrm{CdCl}_{2}$ and $\mathrm{HgCl}_{2}$ at $10^{-4} \mathrm{~mol} / \mathrm{L}$ (Fig. 2b). $\mathrm{HgCl}_{2}$ exhibited cytotoxic effects even at the $1 / 10$ dilutions $\left(10^{-5} \mathrm{~mol} / \mathrm{L}\right)$.

\section{TR ant/agonistic activity of metallic compounds in the yeast assay}

The conventional two-hybrid TR yeast assay performed with $\mathrm{CdCl}_{2}, \mathrm{ZnCl}_{2}, \mathrm{HgCl}_{2}, \mathrm{CuSO}_{4}, \mathrm{MnSO}_{4}$, and $\mathrm{MgSO}_{4}$ revealed that no chemicals exhibited TR-agonistic activities (Fig. 3a). However, the co-administration of the test chemicals with $2.5 \times 10^{-7} \mathrm{~mol} / \mathrm{L} \mathrm{T}_{3}$, which has been shown to induce submaximal $\beta$-galactosidase expression, demonstrated that several of the chemicals suppressed $\beta$-galactosidase activity (Fig. 3b). This inhibition by $\mathrm{ZnCl}_{2}, \mathrm{HgCl}_{2}$, and $\mathrm{CdCl}_{2}$ demonstrated a dose-dependent relationship. The $\mathrm{RIC}_{20}$ values of $\mathrm{ZnCl}_{2}$, $\mathrm{HgCl}_{2}$, and $\mathrm{CdCl}_{2}$ were $9.1 \times 10^{-5}, 3.2 \times 10^{-6}$, and $1.2 \times 10^{-6} \mathrm{~mol} / \mathrm{L}$, respectively. The other chemicals did not 
Fig. 2 a Cytotoxicity of the tested metallic compounds on yeast cells. b Cytotoxicity of the tested metallic compounds on $\mathrm{GH}_{3}$ cells. The cytotoxicity of the samples is represented as the percent inhibition activity. The values are presented as the averages \pm standard error $(n=3)$

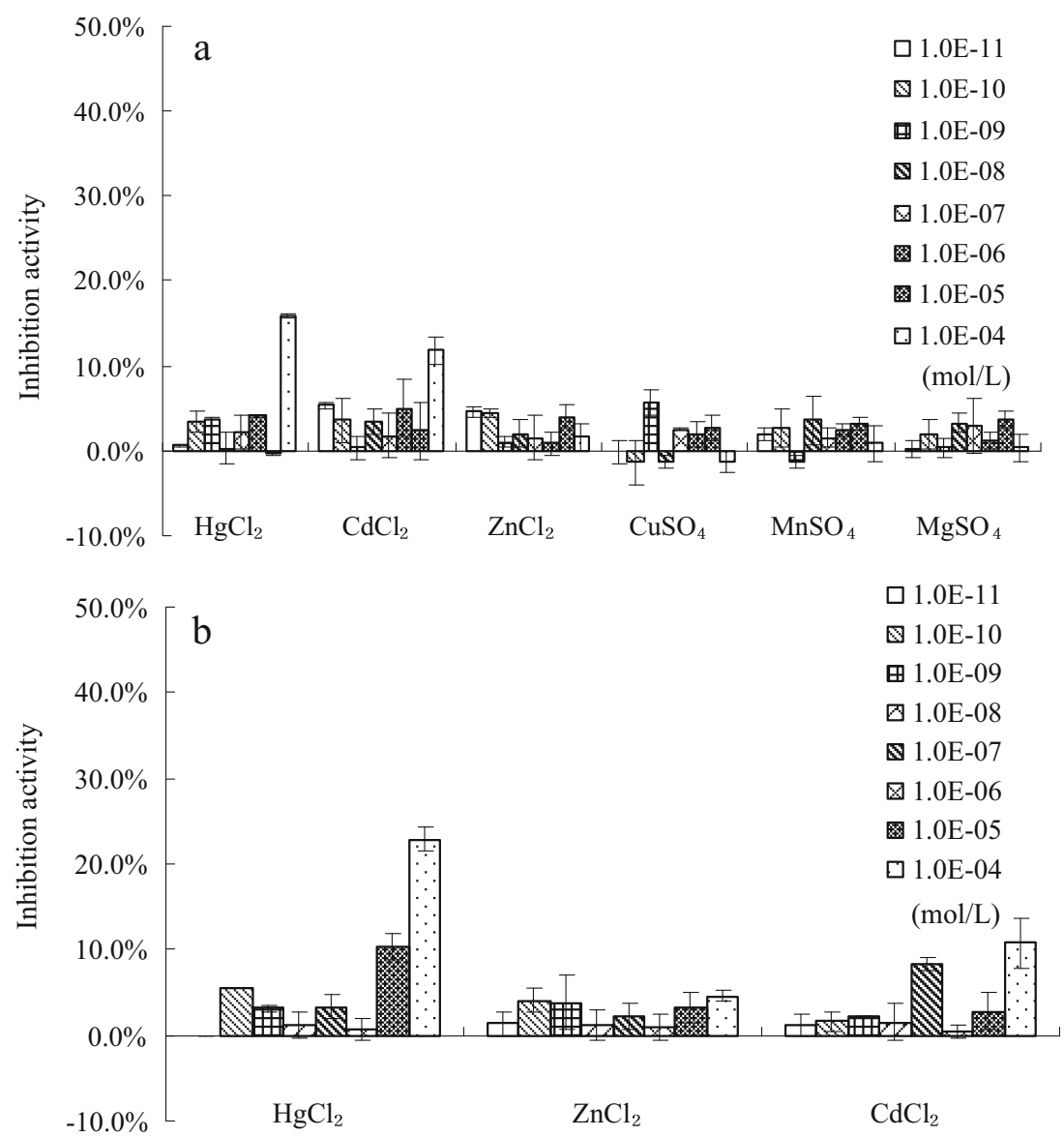

inhibit the $T_{3}$-induced $\beta$-galactosidase activity at the highest concentration that did not show cytotoxicity. As a result, the $\mathrm{RIC}_{20}$ of these chemicals could not be calculated.

\section{TR ant/agonistic activity of metallic compounds in the T-screen}

To validate the T-screen modifications, the $\mathrm{T}_{3}$-dependent $\mathrm{GH}_{3}$ cell proliferation was measured, as shown in the Supporting Information (Fig. S1). The results obtained with the MTT assay correspond to those obtained with the resazurin detection assay (Schriks et al. 2006), with only a slight and insignificant shift in the median-effect concentration $\left(\mathrm{EC}_{50}\right)$ of $\mathrm{T}_{3}$ from $2.0 \times 10^{-10}$ to $6.1 \times 10^{-10} \mathrm{~mol} / \mathrm{L}$ (Fig. S1). Consistent with other reports (Norman and Lavin 1989), AH antagonized the response induced by $2.5 \times 10^{-10} \mathrm{~mol} / \mathrm{L} \mathrm{T}_{3}$ (Fig. S2). AH alone had no effect (data not shown), but at concentrations up to $5 \times 10^{-7} \mathrm{~mol} / \mathrm{L}$, the $\mathrm{T}_{3}$-induced response was significantly decreased. Visible cytotoxicity was observed at $10^{-4} \mathrm{~mol} / \mathrm{L}$. The $\mathrm{RIC}_{20}$ was calculated to be $1.7 \times 10^{-6} \mathrm{~mol} / \mathrm{L}$, which is in good agreement with published results (Schriks et al. 2006).

The effects of the metallic compounds $\left(\mathrm{ZnCl}_{2}, \mathrm{HgCl}_{2}\right.$, and $\mathrm{CdCl}_{2}$ ) on thyroid signaling were evaluated, and TR agonism was not detected (data not listed). The joint action of metallic compounds and $\mathrm{T}_{3}$ on $\mathrm{GH}_{3}$ cells was assessed. Eight concentrations (from $10^{-11}$ to $10^{-4} \mathrm{~mol} / \mathrm{L}$ ) of each compound were tested in combination with $2.5 \times 10^{-10} \mathrm{~mol} / \mathrm{L} \mathrm{T}_{3}$, which induced submaximal cell proliferation. The presence of $\mathrm{ZnCl}_{2}$ in the incubating medium inhibited the $\mathrm{T}_{3}$-induced cell proliferation in a dose-dependent manner (Fig. 4). The maximum inhibition $\left(31.9 \%\right.$ ) was found at a concentration of $10^{-4} \mathrm{~mol} /$ $\mathrm{L} \mathrm{ZnCl}$, which did not have a cytotoxic effect. The $\mathrm{RIC}_{20}$ value of $\mathrm{ZnCl}_{2}$ was calculated to be $3.1 \times 10^{-6} \mathrm{~mol} / \mathrm{L}$. A dosedependent inhibition of the $T_{3}$ thyroidicity was also observed with $\mathrm{HgCl}_{2}$. The thyroidic activity was inhibited significantly with the tested $\mathrm{HgCl}_{2}$ concentration of $10^{-6} \mathrm{~mol} / \mathrm{L}$. At higher concentrations, $\mathrm{HgCl}_{2}$ was toxic to the $\mathrm{GH}_{3}$ cells. Similarly, $\mathrm{CdCl}_{2}$ also reduced the $\mathrm{T}_{3}$-induced cell proliferation, and the maximal-inhibition activity $(26.8 \%)$ was observed at $10^{-5} \mathrm{~mol} / \mathrm{L}$. The $\mathrm{RIC}_{20}$ values of these metallic compounds could not be calculated.

\section{TR antagonistic activity of environmental water samples}

The thyroid-disrupting effects of the water samples were detected by the modified two-hybrid TR yeast assay, revealing that all of the water samples displayed antagonistic TR activities that inhibited $\beta$-galactosidase expression (Fig. 5). The 
Fig. 3 a The agonistic thyroid receptor (TR) activities of the tested metallic compounds were determined using the yeast assay. b The antagonistic thyroid receptor (TR) activities of the tested metallic compounds were determined using the yeast assay. The data represent the results from three independent experiments with three replicates each

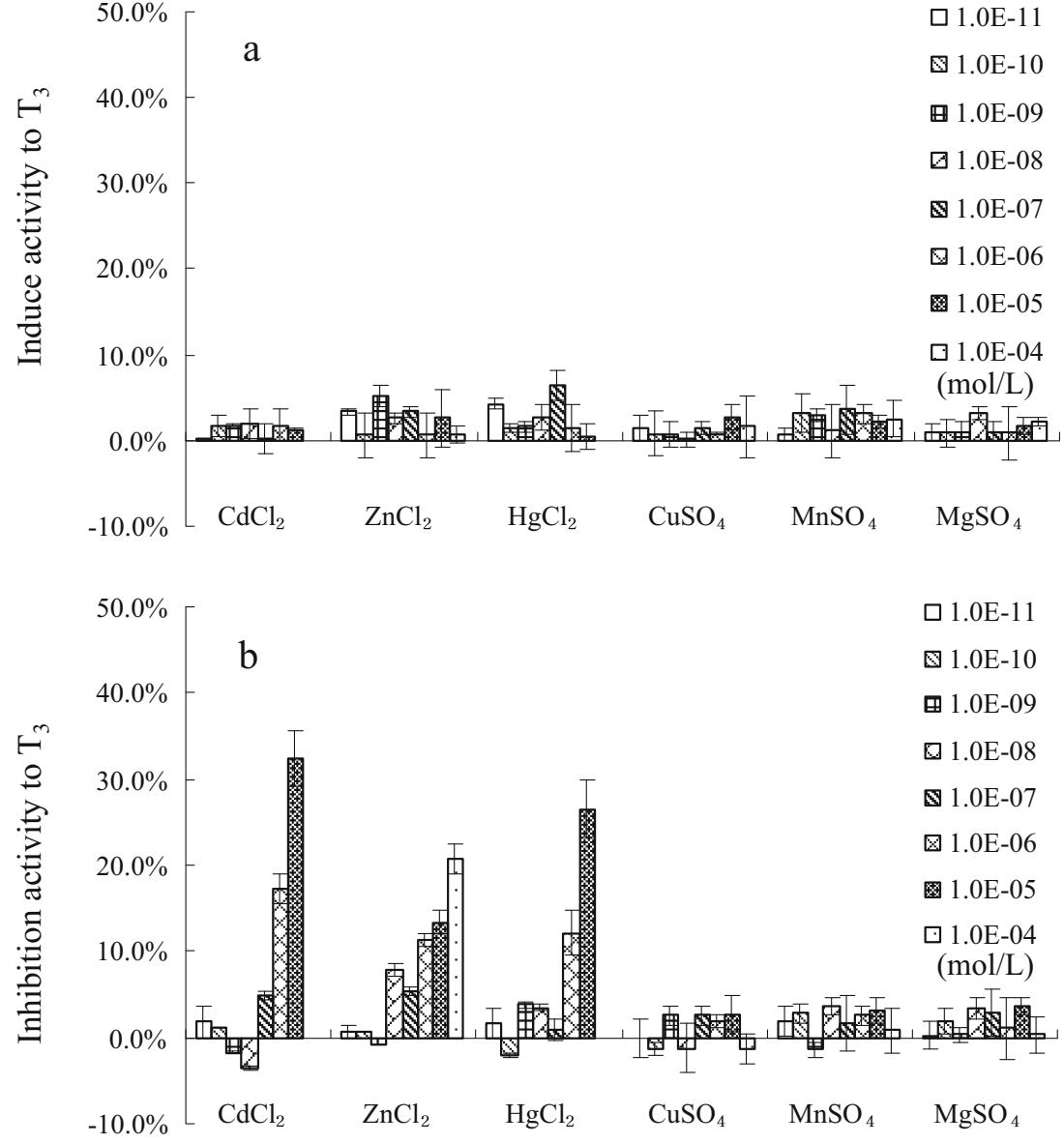

blank samples did not disrupt the TR. Interestingly, after extraction, the thyroid inhibition activities of the residual water decreased (Fig. 5). The extraction could eliminate more than $61.9 \%$ of the total effect produced by the TR antagonists. Several residual water samples (GR1, GR5, and GR6) significantly differed from the negative control $(p<0.05)$, suggesting that several antagonists may be inorganic chemicals and exist in the residual water samples. After the addition of EDTA $(30 \mathrm{mg} / \mathrm{L})$ to the residual water samples, the inhibition activities decreased significantly, and the TR antagonistic

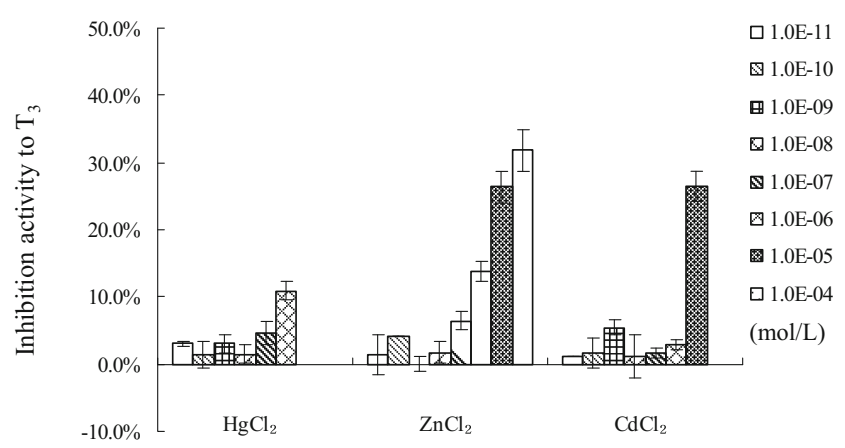

Fig. 4 The antagonistic activities of the tested metallic compounds were determined using the T-screen. The data represent the results from three independent experiments with three replicates each activities for all of the water samples were eliminated, showing that some metals may contribute to the TR antagonistic activity.

Furthermore, the concentrations of $\mathrm{Zn}, \mathrm{Hg}$, and $\mathrm{Cd}$ in the water samples were detected. The results showed that the concentrations of $\mathrm{Hg}$ and $\mathrm{Cd}$ were lower than $10^{-9} \mathrm{~mol} / \mathrm{L}$. However, the concentrations of $\mathrm{Zn}$ ranged from $5.2 \times 10^{-8}$ to $1.6 \times 10^{-7} \mathrm{~mol} / \mathrm{L}$, and the average concentration was $7.9 \times 10^{-8} \mathrm{~mol} / \mathrm{L}$ (Supporting Information).

\section{Discussion}

In vitro methods are valuable and important tools for screening environmental compounds that exhibit potential endocrine-disrupting effects. In the present study, $\mathrm{Mg}^{2+}$ and $\mathrm{Mn}^{2+}$ were not found to disrupt the specific binding of $\mathrm{T}_{3}$ to TR. This result is supported by Surks et al. (1989), who also reported that the concentration dependence responses for $\mathrm{Mn}^{2+}$ and $\mathrm{Mg}^{2+}$ to inhibit $\mathrm{T}_{3}$ binding to TR were not illustrated. $\mathrm{Cu}^{2+}$ was not found disrupting the activity by the twohybrid TR yeast assay, but in the previous work, $\mathrm{Cu}^{2+}$ showed limited ability to dissociate $\mathrm{T}_{3}$ from $\mathrm{TR}$ extracted from cultured cells (Surks et al. 1989). One reason for the difference 
Fig. 5 The antagonistic thyroid receptor (TR) activities of the water samples with various treatments were determined using the modified yeast bioassay. The data represent the results from three independent experiments with three replicates each. C18: solid-phase extraction using a C18 cartridge.

Ethylenediaminetetraacetic acid (EDTA): addition of $30 \mathrm{mg} / \mathrm{L}$ of EDTA

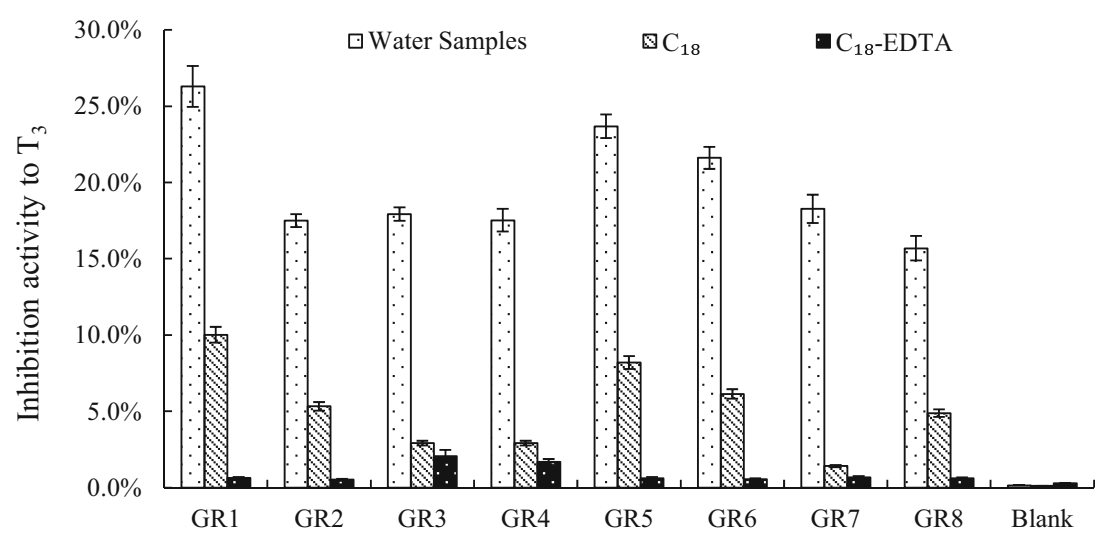

observed between the two bioassays could be the different metal bioavailabilities between the yeast and the extracts of nuclei.

The results of the two-hybrid TR yeast and T-screen assays performed in this study demonstrate the anti-thyroid activity of several divalent metals, including $\mathrm{Zn}^{2+}, \mathrm{Hg}^{2+}$, and $\mathrm{Cd}^{2+}$. Of these metals, particular attention was paid to $\mathrm{Zn}^{2+}$ because $\mathrm{Zn}^{2+}$ is necessary for the formation of the zinc finger structures of nuclear receptors, which play an important role in binding to DNA (Berg 1990). Moreover, Surks et al. (1989) reported that $\mathrm{Zn}^{2+}$ also might play a role in $\mathrm{T}_{3}$ binding to TR. $\mathrm{Zn}^{2+}$ can displace of $\mathrm{T}_{3}$ bound to TR. The addition of $\mathrm{ZnCl}_{2}$ resulted in a concentration-dependent inhibition of the binding of $\mathrm{T}_{3}$ to TR and that the $\mathrm{ZnCl}_{2}$ concentration of $8 \times 10^{-7} \mathrm{~mol} / \mathrm{L}$ resulted in a significant decrease in the specific binding of $\left[{ }^{125} \mathrm{I}\right] \mathrm{T}_{3}$ by TR (Surks et al. 1989), which is consistent with our finding that $\mathrm{ZnCl}_{2}$ significantly inhibited the $\mathrm{T}_{3}$-induced enzyme activity at the concentration of $10^{-6} \mathrm{~mol} / \mathrm{L}$, as determined by the two-hybrid TR yeast assay. The $\mathrm{GH}_{3}$ cell line has been described as a model cell line to study the basic $\mathrm{TH}-$ dependent cell physiology (Hohenwarter et al. 1996). In the present study, we also found that $\mathrm{ZnCl}_{2}$ inhibits $\mathrm{T}_{3}$-dependent $\mathrm{GH}_{3}$ cell proliferation in the concentration range from $10^{-6}$ to $10^{-4} \mathrm{~mol} / \mathrm{L}$. A similar result was reported by Chattopadhyay and Freake (1998), who suggested that the addition of exogenous zinc $\left(\mathrm{ZnSO}_{4}, 10^{-5}-10^{-4} \mathrm{~mol} / \mathrm{L}\right)$ has negative effects on the $\mathrm{T}_{3}$ responsiveness in $\mathrm{GH}_{3}$ cells. The latter study also showed that $\mathrm{Zn}$ inhibits the $\mathrm{T}_{3}$-induced expression of the target proteins, such as fatty acid synthase and malic enzyme, in a dose-dependent manner (Chattopadhyay and Freake 1998). Sciaudone et al. (2000) showed that the restriction of $\mathrm{Zn}^{2+}$ availability with chelators (diethylenetriaminepentaacetic acid or EDTA) enhanced the action of $\mathrm{T}_{3}$ to induce target gene expression in $\mathrm{GH}_{3}$ cells, and that this positive effect could be blocked or reversed by $4 \times 10^{-5} \mathrm{~mol} / \mathrm{L} \mathrm{Zn}^{2+}$. The result argued against a toxic and generalized effect of $\mathrm{Zn}^{2+}$ removal on the cells (Sciaudone et al. 2000). The inhibitory effect of $\mathrm{Zn}^{2+}$ on $\mathrm{T}_{3}$ binding was also reported to be specific for TR and the $\mathrm{Zn}^{2+}$ induced increase in the rate of dissociation of $\mathrm{T}_{3}$ from
TR, which may be due to the interaction of $\mathrm{Zn}^{2+}$ with one or more of the conserved cysteine or histidine residues located within or adjacent to $\mathrm{T}_{3}$-binding site of the receptor (Surks et al. 1989).

Cadmium appears to be the largest single contributor to autoimmune thyroid disease, not only because $\mathrm{Cd}$ appears to play a pivotal role in thyroid disease but also because it is extremely toxic and exerts toxic biological effects at lower concentrations (Goyer et al. 1995). A few studies have reported that $\mathrm{Cd}$ inhibits thyroid function in mammals, fishes, and birds (Gupta and Kar 1999). However, the available data on the thyroid-disrupting effects of $\mathrm{Cd}$ are limited. In the present study, we suggested that $\mathrm{CdCl}_{2}$ inhibits the response induced by $\mathrm{T}_{3}$ and had TR antagonistic activity based on the results of the yeast and T-screen assays. A previous study suggested that $\mathrm{CdCl}_{2}\left(10^{-6}-10^{-4} \mathrm{~mol} / \mathrm{L}\right)$ presented a concentrationdependent inhibition of $\mathrm{T}_{3}$-binding to $\mathrm{TR}$, which is parallel to that observed with $\mathrm{ZnCl}_{2}$, and the half-maximal inhibition occurred at approximately $2 \times 10^{-5} \mathrm{~mol} / \mathrm{L} \mathrm{CdCl}_{2}$ (Surks et al. 1989). This value is consistent with our findings from the twohybrid assay and the T-screen assay. Surks et al. (1989) also suggested that $\mathrm{Cd}^{2+}$, like $\mathrm{Zn}^{2+}$, might displace $\mathrm{T}_{3}$-binding site and decrease the binding affinity of $\mathrm{T}_{3}$ with $\mathrm{TR}$.

In the present study, $\mathrm{Hg}$ showed different cytotoxicity to the yeast and $\mathrm{GH}_{3}$ cells, which is likely due to the differential susceptibility of these cells to $\mathrm{HgCl}_{2}$. However, the results of the anti-thyroid activity test by the two-hybrid TR yeast assay, as well as the inhibition of the $\mathrm{T}_{3}$-induced cell proliferation, as tested by the T-screen assay, suggest that $\mathrm{Hg}^{2+}$ may interrupt the thyroid function by regulating the TH-receptor signaling pathway. Few studies have examined the relationship between $\mathrm{HgCl}_{2}$ exposure and direct thyrotoxicity. It has been suggested that men subjected to long-term workplace exposure to $\mathrm{Hg}$ may have a higher concentration of $\mathrm{Hg}$ in the thyroid and the pituitary than in the liver or the kidney (Kosta et al. 1975). A previous study also showed a relationship between Hg exposure and TH imbalance (Dundar et al. 2006). Sin et al. (1990) reported that the serum $\mathrm{T}_{4}$ and $\mathrm{T}_{3}$ decreased significantly in $\mathrm{HgCl}_{2}$-treated mice. However, the possible 
mechanisms underlying the toxic effects of $\mathrm{Hg}$ are also discussed, and the effects of exposure to $\mathrm{Hg}$ on human thyroid function still require further confirmation.

It is very interesting that $\mathrm{Zn}, \mathrm{Cd}$, and $\mathrm{Hg}$ are included in group IIB in the periodic table. It has been reported that the members of this group show patterns in its electron configuration, especially the outermost shells, which result in trends in their chemical behavior. All of these may help to understand their TR-disrupting activities. Although the TR-antagonistic activities of $\mathrm{ZnCl}_{2}, \mathrm{HgCl}_{2}$, and $\mathrm{CdCl}_{2}$ were detected in the yeast and $\mathrm{T}$-screen assays, several differences between these assays were evident. For example, the yeast assay gave a higher $\mathrm{RIC}_{20}$ value of $\mathrm{ZnCl}_{2}$ than the $\mathrm{GH}_{3}$ cell line. This variation could be due to the differences in the test mechanism of the assays. The $\mathrm{GH}_{3}$ cells constitutively express both TR isoforms, and the TH-induced proliferation of $\mathrm{GH}_{3}$ cells was used as the basis for the T-screen. The cell proliferation is an entirely genomic TR-mediated mechanism (Freitas et al. 2011). However, the two-hybrid yeast cell was simply transferred with $\mathrm{hTR} \beta$, and the yeast cell was stably transfected with a thyroid-hormone-response-element-regulated $\beta$ galactosidase reporter gene, enabling the detection of a thyroid receptor-specific endpoint.

Heavy metals are widely dispersed in the environment. Steady population growth and industrialization have led to an increase in metal pollutants in the aquatic environment. Metal pollutants are distributed between the overlying water and the sediment, and the sediment has become the sink of these pollutants. Metal pollutants are a source of grave concern because of their toxicity, persistence, and accumulation. Measuring the toxic effects of heavy metals in aquatic environments may be important to obtain information regarding their impact on organism and ecosystem health. In the present study, pollutant extraction was performed, and the water samples collected from the Guanting Reservoir significantly inhibited the $\mathrm{T}_{3}$-induced $\beta$-galactosidase activity. After the addition of EDTA, the inhibition was eliminated. The water samples have been shown to contain various heavy metals, such as $\mathrm{Zn}, \mathrm{Cd}$, and $\mathrm{Hg}$, and the concentrations of $\mathrm{Zn}$ were equal or slightly lower than the lowest-observed-effect concentration. Although the major thyroid hormone-disrupting metals in the water samples have not yet been identified, these results are very promising for further research on the presence of thyroid hormone-disrupting metals in environmental water samples.

\section{Conclusion}

In summary, a two-hybrid yeast assay and a T-screen assay were utilized to identify the TR-agonistic and antagonistic activities of metallic compounds and water samples collected from the Guanting Reservoir. Our results suggest that $\mathrm{ZnCl}_{2}$,
$\mathrm{HgCl}_{2}$, and $\mathrm{CdCl}_{2}$ inhibit the $\mathrm{T}_{3}$-induced responses and may have anti-thyroid activity. Moreover, the metallic compounds in the water samples may affect TH signaling by decreasing the binding of the standard TR ligand $\left(\mathrm{T}_{3}\right)$. In future studies, the chemical forms of the heavy metals in the water samples will be analyzed to identify the major forms of the thyroid hormone-disrupting metals.

Acknowledgments This study was supported by the National Natural Science Foundation of China (41001351), the Fundamental Research Funds for the Central Universities (2012LYB35), and the Major Science and Technology Program for Water Pollution Control and Treatment (2014ZX07201-010).

\section{References}

Ali I, Penttinen-Damdimopoulou PE, Mäkelä SI, Berglund M, Stenius U, Akesson A, Håkansson H, Halldin K (2010) Estrogen-like effects of cadmium in vivo do not appear to be mediated via the classical estrogen receptor transcriptional pathway. Environ Health Perspect 118:1389-1394. doi:10.1289/ehp.1001967

Berg J (1990) Zinc fingers and other metal-binding domains. Elements for interactions between macromolecules. J Biol Chem 265:65136516

Boas M, Feldt-Rasmussen U, Main KM (2012) Thyroid effects of endocrine disrupting chemicals. Mol Cell Endocrinol 355:240-248. doi: 10.1016/j.mce.2011.09.005

Buha A, Antonijevic B, Bulat Z, Jacevic V, Milovanovic V, Matovic V (2013) The impact of prolonged cadmium exposure and coexposure with polychlorinated biphenyls on thyroid function in rats. Toxicol Lett 221:83-90. doi:10.1016/j.toxlet.2013.06.216

Chattopadhyay S, Freake HC (1998) Zinc chelation enhances thyroid hormone induction of growth hormone mRNA in $\mathrm{GH}_{3}$ cells. Mol Cell Endocrinol 136:151-157. doi:10.1016/S0303-7207(97)002281

Curčić M, Jankovic S, Jacevic V, Stankovic S, Vucinic S, Durgo K, Bulat Z, Antoni-jevic B (2012) Combined effects of cadmium and decabrominated diphenylether on thyroid hormones in rats. Arh Hig Rada Toksikol 63:255-262. doi:10.2478/10004-1254-632012-2179

Denier X, Hill EM, Rotchell J, Minier C (2009) Estrogenic activity of cadmium, copper and zinc in the yeast estrogen screen. Toxicol In Vitro 23:569-573. doi:10.1016/j.tiv.2009.01.006

Dundar B, Oktem F, Arslan KM, Delibas N, Baykal B, Arslan C, Gultepe M, Ilhan EI (2006) The effect of long-term low-dose lead exposure on thyroid function in adolescents. Environ Res 101:140-145. doi: 10.1016/j.envres.2005.10.002

Freitas J, Cano P, Craig-Veit C, Goodson ML, Furlow JD, Murk AJ (2011) Detection of thyroid hormone receptor disruptors by a novel stable in vitro reporter gene assay. Toxicol In Vitro 25:257-266. doi: 10.1016/j.tiv.2010.08.013

Fu J, Zhao C, Luo Y, Liu C, Kyzase GZ, Luo Y, Zhao D, An S, Zhu H (2014) Heavy metals in surface sediments of the Jialu River, China: their relations to environmental factors. J Hazard Mater 270:102 109. doi:10.1016/j.jhazmat.2014.01.044

Goyer RA, Klaassen CD, Waalks MP (1995) Metal toxicology. Academic, San Diego, pp 21-36

Gupta P, Kar A (1999) Cadmium induced thyroid dysfunction in chicken: hepatic type I iodothyronine 5\%-monodeiodinase activity and role of lipid peroxidation. Comp Biochem Physiol C Pharmacol Toxicol Endocrinol 123:39-44. doi:10.1016/S0742-8413(99)00007-9 
Gupta P, Chaurasia SS, Kar A, Maiti PK (1997) Influence of cadmium on thyroid hormone concentrations and lipid peroxidation in a fresh water fish, Clarias batrachus. Fresen Environ Bull 6:355-358

Gutleb AC, Meerts IA, Schriks M, Murk AJ (2005) T-Screen as a tool to identify thyroid hormone receptor active compounds. Environ Toxicol Pharmacol 19:231-238. doi:10.1016/j.etap.2004.06.003

Hammouda F, Messaoudi I, El Hani J, Baati T, Saïd K, Kerkeni A (2008) Reversal of cadmium-induced thyroid dysfunction by selenium, zinc, or their combinationin rat. Biol Trace Elem Res 126:194 203. doi:10.1007/s12011-008-8194-8

Hohenwarter O, Waltenberger A, Katinger H (1996) An in vitro test system for thyroid hormone action. Anal Biochem 234:56-59. doi: 10.1006/abio.1996.0049

Isidori M, Cangiano M, Palerma A (2010) E-screen and vitellogenin assay for the detection of the estrogenic activity of alkylphenols and trace elements. Comp Biochem Physiol C Toxicol Pharmacol 152:51-56. doi:10.1016/j.cbpc.2010.02.011

Kosta L, Byrne AR, Zelenko V (1975) Correlation between selenium and mercury in man following exposure to inorganic mercury. Nature 254:238-239. doi:10.1038/254238a0

Li J, Ma M, Wang Z (2008) A two-hybrid yeast assay to quantify the effects of xenobiotics on thyroid hormone-mediated gene expression. Environ Toxicol Chem 27:159-167. doi:10.1897/07-054.1

Li J, Wang Z, Ma M, Peng X (2010) Analysis of environmental endocrine disrupting activities using recombinant yeast assay in wastewater treatment plant effluents. Bull Environ Contam Toxicol 84:529 535. doi:10.1007/s00128-010-0004-2

Li J, Ren SJ, Han SL, Li N (2014) A yeast bioassay for direct measurement of thyroid hormone disrupting effects in water without sample extraction, concentration, or sterilization. Chemosphere 100:139 145. doi:10.1016/j.chemosphere.2013.11.054

Lukaski HC, Hall CB, Marchello MJ (1995) Body temperature and thyroid hormone metabolism of copper-deficient rats. J Nutr Biochem 6:445-451. doi:10.1016/0955-2863(95)00062-5

Martins VV, Zanetti MO, Pitondo-Silva A, Stehling EG (2014) Aquatic environments polluted with antibiotics and heavy metals: a human health hazard. Environ Sci Pollut Res Int 21:5873-5878. doi:10. 1007/s11356-014-2509-4

Murk AJ, Rijntjes E, Blaauboer BJ, Clewell R, Crofton KM, Dingemans MM, Furlow JD, Kavlock R, Kohrle J, Opitz R, Traas T, Visser TJ, Xia M, Gutleb AC (2013) Mechanism-based testing strategy using in vitro approaches for identification of thyroid hormone disrupting chemicals. Toxicol In Vitro 27:1320-1346. doi:10.1016/j.tiv.2013. 02.012
Norman MF, Lavin TN (1989) Antagonism of thyroid hormone action by amiodarone in rat pituitary tumor cells. J Clin Invest 83:306-313. doi:10.1172/JCI113874

Rehmann RK, Schramm KW, Kettrup AA (1999) Applicability of a yeast oestrogen screen for the detection of oestrogen-like activities in environmental samples. Chemophere 38:3303-3312. doi:10.1016/ S0045-6535(98)00562-1

Schriks M, Vrabie CM, Gutleb AC, Faassen EJ, Rietjens IM, Murk AJ (2006) T-screen to quantify functional potentiating, antagonistic and thyroid hormone-like activities of poly halogenated aromatic hydrocarbons (PHAHs). Toxicol In Vitro 20:490-498. doi:10.1016/j.tiv. 2005.09.001

Sciaudone MP, Chattopadhyay S, Freake HC (2000) Chelation of zinc amplifies induction of growth hormone mRNA levels in cultured rat pituitary tumor cells. J Nutr 130:158-163

Shi X, Liu C, Wu G, Zhou B (2009) Waterborne exposure to PFOS causes disruption of the hypothalamus-pituitary-thyroid axis in zebrafish larvae. Chemosphere 77:1010-1018. doi:10.1016/j.chemosphere. 2009.07.074

Shiue I (2015) Urinary heavy metals, phthalates and polyaromatic hydrocarbons independent of health events are associated with adult depression: USA NHANES, 2011-2012. Environ Sci Pollut Res Int 22:17095-17103. doi:10.1007/s11356-015-4944-2

Sin YM, Teh WF, Wong MK, Reddy PK (1990) Effect of mercury on glutathione and thyroid hormones. Bull Environ Contain Toxicol 44:616-622

Sirbasku DA, Pakala R, Sato H, Eby JE (1991) Thyroid hormone dependent pituitary tumor cell growth in serum-free chemically defined culture. A new regulatory role for apotransferrin. Biochem 30:74667477. doi:10.1021/bi00244a015

Surks MI, Ramirez IJ, Shapiro LE, Kumara-Siri M (1989) Effect of zinc (II) and other divalent cations on binding of 3,5,3'-triiodo-Lthyronine to nuclear receptors from cultured GC cells. J Biol Chem 264:9820-9826

Wada L, King JC (1986) Effect of low zinc intakes on basal metabolic rate, thyroid hormones and protein utilization in adult men. J Nutr 116:1045-1053

Yaman M, Kaya G, Yekeler H (2007) Distribution of trace metal concentrations in paired cancerous and non-cancerous human stomach tissues. World J Gastroenterol 13:612-618

Yen PM, Ando S, Feng X, Liu Y, Maruvanda P, Xia X (2006) Thyroid hormone action at the cellular, genomic and target gene levels. Mol Cell Endocrinol 246:121-127 